$$
\text { 水分がポリプロピレンの光劣化に及ぼす影響 }
$$

\author{
飯塚 智則*** 大武 義人* 田中 敬二**,***
}

\title{
A Effect of Moisture on Photo-Degradation for Polypropylene
}

\author{
by
}

\author{
Tomonori IIZUKA*,**, Yoshito OHTAKE*and Keiji TANAKA**,***
}

\begin{abstract}
Photo-degradation of polymers for outdoor use are accelerated by degradation factors such as heat and moisture. Polypropylene (PP) is excellent in water resistance, but is inferior to weatherability. Therefore, in this study, PP was exposed under the water spray condition by using Xenon arc lamp. We evaluated the synergistic effect of light and moisture using the quantification technique of degradation. Results from the Fourier-transform infrared spectroscopic and X-ray Photoelectron Spectroscopy revealed that moisture accelerated the oxidative degradation of PP. In addition, with the progress of the oxidative degradation, melting point and thermal decomposition temperature of PP was lowered. The resulting collapse of crystal structure and chain scission therefore deteriorated the mechanical properties (Charpy impact strength, elongation ) of PP.
\end{abstract}

Key words: Photo-degradation, Polypropylene, Weatherability, Xenon, Moisture

\section{1 緒言}

屋外で使用される樹脂材の劣化は光や熱等が基本因 子となる自動酸化反応により進行する.この他の劣化因 子として, 降雨, 結露, 湿度による水分 ${ }^{1)}$, 2), 大気中の オゾン 3), 4)，さらには微生物 5), 6)などが挙げられ，これ らは光や熱と複雑に絡み合い劣化が相乗的に促進され る。とりわけ湿度が高く降水量が多い我が国の気象条件 を鑑みると，水噴霧や結露の条件設定は促進試験を実施 するうえで久かせない劣化因子といえる.

水分による主な劣化現象として乾湿の繰り返しによ り成形品表面上に生じたひずみやき裂がもたらす強度 低下が挙げられ，材料の吸水性も劣化に影響を及ぼす。 親水基を有する分子構造をもつ樹脂材は高い吸水性を 示す．汎用樹脂材のうちヒドロキシ基 $(\mathrm{OH})$ をもつポリ ビニルアルコールは吸水率が 5\%以上, カルボキシ基 (C $\mathrm{OOH}$ )をもつポリ䣷酸ビニルやアミド基 $\left(\mathrm{NH}_{2}\right)$ をもつ ポリアミドも吸水率が $1 \%$ 以上である. エステル結合を もつメタクリル樹脂やポリエチレンテレフタレートの 吸水率は $0.1 \sim 1 \%$ あ゙あ. 吸水された水分は材料の表面 から内部へ拡散浸透し, 加水分解等により分子量やガラ 又転移点の低下が生じ 7) 9), 成形品としての機能を低 下させる。また，長寿命化を図るための酸化防止剂や光 安定剂等の添加剂が水により流出することで劣化防止 効果が失われ，劣化が急激に進行することもある ${ }^{10)}$.

一方，ポリオレフィン系樹脂の代表であるポリプロピ レン（PP） は親水基を有さず結晶性を示すため, 吸水率 は $0.1 \%$ 以下と低く耐水性に優れる.しかし，主鎖にメチ ル基が結合した 3 級炭素を有しているため, 耐候性に劣 る。そこで我々は劣化促進下における水の影響について の定量的考察が少ない現状であるため, 光照射時の水分 の影響について PP を用いて検討を行った.

\section{2 実験 \\ 2.1 供試料と試料形状}

日本ポリプロ社製のアイソタクチック PP(ノバテック PPMA3，メルトフローレート： $11 \mathrm{~g} / 10 \mathrm{~min}$, 密度 : 0.90 $\left.\mathrm{g} / \mathrm{cm}^{3}\right)$ をシリンダー温度 $200^{\circ} \mathrm{C}$ の射出成型加工により, 厚さ $4 \mathrm{~mm}$ のプレートおよびシャルピー衝撃試験片（JIS K 7111 規定，1eA 形），また，引張試験片（JIS K 7161 規 定, $1 \mathrm{~A}$ 形) を作製した。供試料中に酸化防止剂が添加さ れている可能性を検討するため, ジクロロメタンにて 16 時間ソックスレー抽出後, 抽出物をガスクロマトグラフ 質量分析により定性定量分析を実施した。 その結果, 試 料にはリン系加工安定剤 Tris(2,4-ditert-butylphenyl) phosphite が $1.7 \times 10^{-2} \%$ と極微量含まれることを確認し たが，本研究の評価分析にほとんど影響しないと判断し た.

\section{2 促進暴露処理方法}

スガ試験機社製キセノンアークランプ（SX2D-75)を 用い，Table 1 に示寸条件にて実施した。促進暴露は JIS K 7350-2「プラスチックー実験室光源による暴露試験方 法一第 2 部 : キセノンアークランプ」の規定に従い, 放 射照度 $60 \mathrm{~W} \cdot \mathrm{m}^{-2}$, ブラックパネル温度 $63{ }^{\circ} \mathrm{C}$, 照射時の 相対湿度 $50 \% \mathrm{RH}$ は条件(1)「水噴霧あり」と条件(2)「水 噴霧なし」で共通とし，条件(1)の水噴霧サイクルは 120 分間照中に 18 分間水噴霧を行う設定とした. インナー フィルタは石英, アウターフィルターは屋外用のデイラ イトフィルタ\#295 を使用することで, $295 \mathrm{~nm}$ 以下の短 波長側をカットした。光照射処理時間は $50,100,250$, 500 時間の 4 水準について行った. 処理後の試験片は, JIS 規定の標準状態 $\left(23 \pm 2^{\circ} \mathrm{C} ， 50 \pm 5 \% \mathrm{RH}\right)$ の雾囲気下で 24 時間以上状態調整を行ない評価に供した.

†原稿受理＼cjkstart平成28年2月13日 Received Feb.13,2016 @2016 The Society of Materials Science, Japan

*一般財団法人化学物質評価研究機構 $=345-0043$ 埼玉県北葛飾郡杉戸町

Chemicals Evaluation and Research Institute, Kitakatsushika-gun, Saitama 345-0043.

**九州大学大学院統合新領域学府オートモーティブサイエンス専攻 †819-0395 福岡市西区元岡

Department of Automotive Science, Graduate School of Integrated Frontier Sciences, Kyushu University, Nishi-ku, Fukuoka 819-0395.

***九州大学大学院工学研究院 応用化学部門 干819-0395 福岡市西区元岡

Department of Applied Chemistry, Kyushu University, Nishi-ku, Fukuoka 819-0395. 
Table 1 Xenon-arc irradiation conditions.

\begin{tabular}{lcc}
\hline Condition & $(1)$ & $(2)$ \\
\hline Irradiance $/ \mathrm{W} \cdot \mathrm{m}^{-2}$ & 60 & 60 \\
Black panel temperature $/{ }^{\circ} \mathrm{C}$ & 63 & 63 \\
Water spray cycle & 18 min water spray / & - \\
\hline
\end{tabular}

\section{3 暴露処理後の評価}

2.3.1 FT-IR (顕微反射法), XPS による表面分析と水分 測定 暴露表面における分子鎖凝集状態の変化は，フー リ工変換赤外吸収分光測定（FT-IR）の波数 $1715 \mathrm{~cm}^{-1}$ で 観測されるカルボニル基（ $\mathrm{C}=\mathrm{O} ）$ の吸収ピーク強度に基 づき評価した。装置にはバイオ・ラッドラボラトリーズ 社製FTS6000 を用い, 顕微反射モードで測定した. また, ミクロトームにて暴露面から $100 \mu \mathrm{m}$ の深さ範囲までの 試料を切り出し，三菱化学社製 CA-200 を用いてカール フィッシャー法（電量滴定）により暴露面近傍における 水分量を測定した。 XPS による暴露表面の分析は試料 の暴露最表面に銅製メッシュ（75/200メッシュ）をカー ボンテープで固定し，コロネン $\left(\mathrm{C}_{24} \mathrm{H}_{12}\right)$ のイオン源に よりエッチング処理後, Kratos Analytical 社製 X 線光電 子分析装置 (XPS，AXIS-Nova）を用い，X 線光源 $\mathrm{Al} \mathrm{K \alpha}$ $(1486.6 \mathrm{eV})$, 放出角度 $45^{\circ}$, 加速電圧 $15 \mathrm{kV}$, エミッ ション電流 $10 \mathrm{~mA}$ の条件にて $\mathrm{C} 1_{\mathrm{s}}$ スペクトルを測定し た。暴露最表面から速度 $20 \mathrm{~mm} / \mathrm{min}$ で深さ $200 \mathrm{~nm}$ まで エッチング処理を行い， $\mathrm{C} 1_{\mathrm{s}}$ および $\mathrm{O} 1_{\mathrm{s}}$ スペクトルより 得られたデプスプロファイルから酸化劣化の進行深さ を評価した。

2.3.2 暴露表面近傍の構造解析と物性評価 ミクロ卜 一ムにて暴露面から $100 \mu \mathrm{m}$ の深さ範囲までの試料を切 り出し, 示差走査熱量計 (DSC) により融点, 熱重量分 析（TG）により熱分解温度を測定した．融点測定ではメ トラー社製 DSC $823^{\mathrm{e}}$ ，熱分解温度測定ではメトラー社製 $\mathrm{STAR}^{\mathrm{e}}$ sysytem を用い, 窒素雰囲気中にて昇温速度 $10{ }^{\circ} \mathrm{C}$ /min で測定した.

物性試験において, 衝撃特性は JIS K 7111-1「プラス チックーシャルピー衝撃特性の求め方一第 1 部 : 非計装 化衝撃試験」, 引張特性は JIS K 7161「プラスチックー 引張特性の求め方」に従った。 引張試験は速度 $50 \mathrm{~mm}$. $\mathrm{min}^{-1}$ で行い，降伏時の強度と伸びを測定した。また，日 本電子社製 JSM-5610LV の走査型電子顕微鏡（SEM）を 使用し, 加速電圧 $10 \mathrm{kV}$ にて暴露表面の形態観察を行っ た.

\section{3 結果と考察}

\section{1 水分が暴露面の光劣化に及ぼす影響}

Fig. 1 は「水噴霧あり」, Fig. 2 は「水噴霧なし」のFTIR スペクトルである。「水噴霧あり」の照射 250 時間で はカルボニル化合物であるケトン $\left(1715 \mathrm{~cm}^{-1}\right)$ が明瞭に 生じていた。さらに，照射 500 時間ではケトンは著しく 増加し, ケトンの他にもカルボン酸 $\left(1705 \mathrm{~cm}^{-1}\right)$, アルデ ヒド $\left(1730 \mathrm{~cm}^{-1}\right)$, エステル $\left(1740 \mathrm{~cm}^{-1}\right)$ のカルボニル化 合物も確認された。この結果は主に PP が光エネルギー を受け連鎖的に生成したアルコキシラジカルから $\beta$ 開裂 反応がより誘発されたことを示している．同時に，酸化 劣化の進行による主鎖中の $\mathrm{C}=\mathrm{C}\left(1640 \mathrm{~cm}^{-1}\right)$ の吸収ピー クも照射 250 時間より出現していた ${ }^{11)}$. 一方,「水噴霧 なし」でも酸化劣化の進行は認められるもののカルボニ ル化合物を示す吸光度は「水噴霧あり」よりも小さいこ とから, 水分は酸化劣化の進行を助長させるといえる.

また，Fig. 2「水噴霧なし」の照射 500 時間と比べ, Fig. 1「水噴霧あり」では照射 250 時間から，3200～3600 $\mathrm{cm}^{-1}$ 付近にヒドロキシ基の吸収ピークが認められた。こ の要因のひとつとして, 光エネルギーを受けた水分が $\mathrm{H}^{+}$ と $\mathrm{OH}$ に遊離されることで，同様に光エネルギーにより 生じた PP の活性なアルコキシルラジカルから $\mathrm{H}$ 引抜き 反応を助長させ，その結果，アルコール等のヒドロキシ 基 $\left(3400 \mathrm{~cm}^{-1}\right)$ を有する劣化生成物が生じたと考えられ $3^{12)}$.

Fig. 3 は劣化生成量が顕著であった $1715 \mathrm{~cm}^{-1}$ 付近の ケトンの吸光度を $1458 \mathrm{~cm}^{-1}$ 付近の $\mathrm{CH}$ 変角振動の吸光 度で除算して得られたカルボニル Index と照射時間の関 係である ${ }^{13)}$ 。照射 100 時間より水噴霧の有無によるカ ルボニル指標に差異が生じ始め，250 時間に達すると顕 著になり, 水分の影響を受けた酸化劣化の進行度合が大 きく異なる.

露面表面近傍から切り出した試料を $40^{\circ} \mathrm{C}$ の真空オー ブンにて 48 時間脱気後, カールフィッシャー法により 分子鎖に吸着している吸着水分量を測定した. Table 2 および Fig. 4 は吸着水分量と照射時間の関係である.

「水噴霧あり」では「水噴霧なし」と比べ，各照射時間 で多くの吸着水分量が認められた。照射 250 時間から吸 着水分量に顕著な差異が生じ, これはカルボニル Index の増加傾向 (Fig. 3) と良く対応している. 一方, 照射時 の試料表面温度に近い $60^{\circ} \mathrm{C}$ の温水中に光照射を行わず 浸漬させた試料では，500 時間においてもほとんど水分 の吸着は生じていない。このことから非極性ポリマーの PP が酸化劣化により分子鎖中にケトンを主としたカル ボニル基を生成する。このカルボニル基は電子吸引性を 有する親水基であるため，僅かではあるが PP は水分を 吸着する. 吸着された水分により PP の分子鎖間距離は 拡大し, 分子間力が低下したことが光劣化の促進化につ ながったものと推察される。よって，「水噴霧あり」では カルボニル化合物に代表される親水基の増加が顕著に 認められた. その結果, PP 中への水分吸着性が強くなり, 分子間力の低下により光劣化が促進されると考えられ る. 以上，光照射時の水分の付加は劣化生成物がより多 くの水分を吸着することで，光劣化をより進行させてい る. 暴露表面ではカルボニル指標の上昇から推定される 酸化劣化の進行度合いとカルボニル基やヒドロキシ基 等の親水基の付与に伴う吸着水分量の増加傾向に相関 性があるといえる。

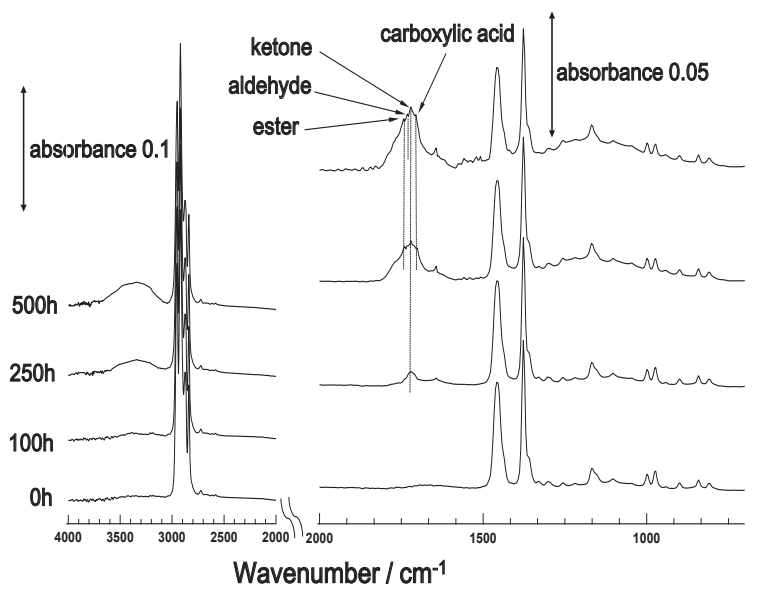

Fig.1 FT-IR spectra for PP oxidized under the condition of (1)(Spray). 


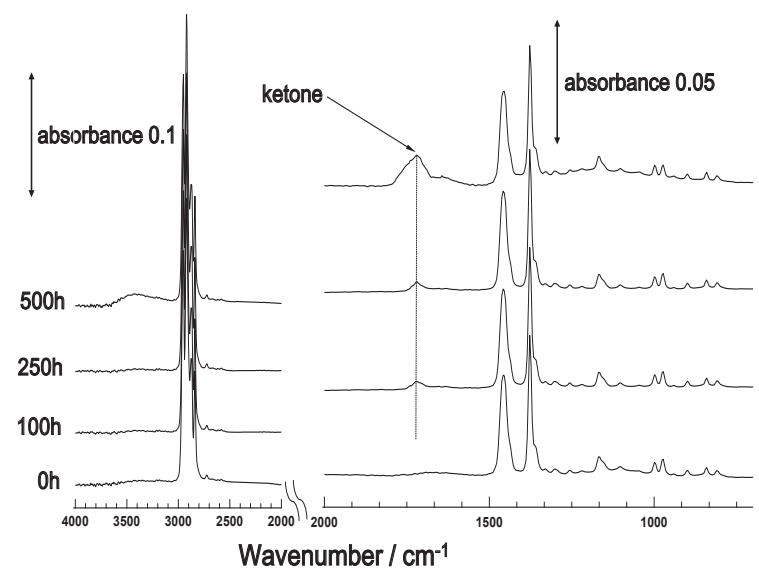

Fig.2 FT-IR spectra for PP oxidized under the condition of (2)(No Spray).

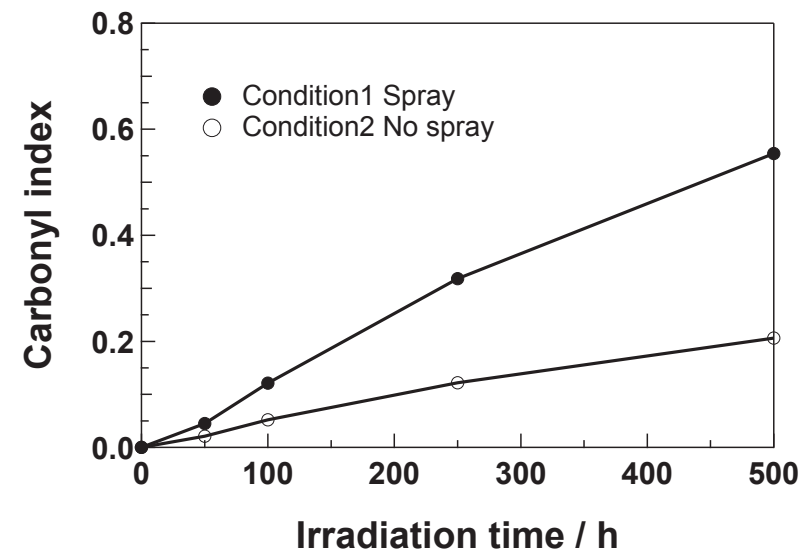

Fig.3 Time dependence of carbonyl index for PP oxidized under the condition of (1)(spray) and (2)(No spray). Carbonyl index is defined as the absorbance ratio of $1715 \mathrm{~cm}^{-1}$ to $1458 \mathrm{~cm}^{-1}$.

Table 2 Change of moisture absorption in exposure surface before and after Xenon irradiation.

\begin{tabular}{ccc}
\hline \multirow{2}{*}{ Irradiation time } & \multicolumn{2}{c}{ Moisture absorption * $\mu \mathrm{g} / \mathrm{g}$} \\
\cline { 2 - 3 } & Condition(1) & Condition(2) \\
\hline $50 \mathrm{~h}$ & Less than 100 & Less than 100 \\
$100 \mathrm{~h}$ & 201 & Less than 100 \\
$250 \mathrm{~h}$ & 506 & 184 \\
$500 \mathrm{~h}$ & 1019 & 608 \\
\hline
\end{tabular}

※KARL-FISCHER Coulometric titration method

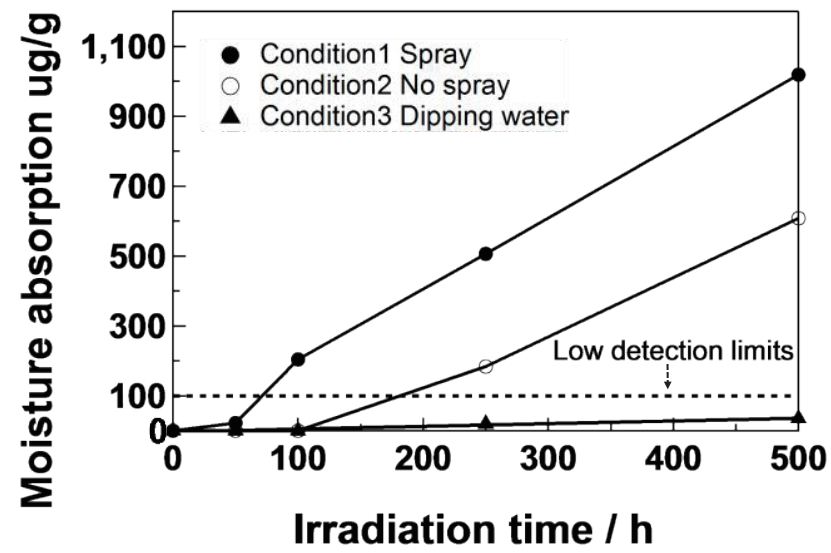

Fig.4 Change of moisture absorption in exposure surface before and after Xenon irradiation.
3.2 水分が暴露表面から深さ方向に対する光劣化の進 行に及ぼす影響

光劣化に水分が関与すると暴露最表面もしくはその 近傍では酸化劣化が促進されることを確認された。さら に, 暴露最表面における酸化生成物の生成量から浸透深 さをXPSにより測定した. Fig. 5 は照射時間ごとにおけ る $\mathrm{O} 1 \mathrm{~s}$ スペクトルと $\mathrm{C} 1 \mathrm{~s}$ スペクトルのピーク面積比に 対するデプスプロファイルである.

照射100時間では「水噴霧あり」,「水噴霧なし」の両条

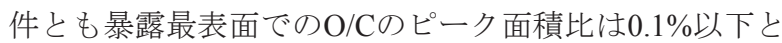
酸化物の生成量は低く, 酸化生成物は深さ $10 \mathrm{~nm}$ 以内で あった。一方，「水噴霧あり」の照射250時間では暴露最

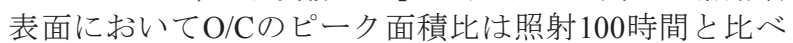
倍増し,「水噴霧なし」と比べ酸化生成物の生成量に有意 差が認められた。 また, 酸化生成物は深さ $100 \mathrm{~nm}$ 付近ま で生じ，水分の影響を受け酸化劣化が深部へ進行したと いえる.さらに，「水噴霧あり」の照射500時間ではO/Cの ピーク面積比が深さ10 $\mathrm{nm}$ 以内で急激な増加を示すと伴 に深さ $200 \mathrm{~nm}$ 付近まで酸化物生成物が確認された。よっ て，水分により暴露面近傍と同時に深さ方向にかけても 酸化劣化が進行したと考えられる.

Fig. 6 は「水噴霧あり」, Fig. 7 は「水噴霧なし」の照 射 500 時間後の暴露最表面における $\mathrm{C} 1 \mathrm{~s}$ スペクトルで ある. 各 $\mathrm{C} 1 \mathrm{~s}$ スペクトルから C-H $(285 \mathrm{eV})$, 酸化生成 物 $\mathrm{C}-\mathrm{O}(286 \mathrm{eV}), \mathrm{C}=\mathrm{O}(288 \mathrm{eV})$ についてピーク分離 を行った ${ }^{14)}$ 。「水噴霧なし」の試料では, 顕著に水分の 影響を受け，C-O (エーテル，ヒドロキシ基由来)， $\mathrm{C}=\mathrm{O}$

（カルボニル基由来）がより多く生成していた。この結 果はFT-IRの吸収ピークの変化（Fig. 1, Fig. 2）と良く 対応している。よって，ヒドロキシ基やカルボニル基な ど親水基を有する生成物の増加に伴い吸着水分量が増 加する. 寸なわち, 水と光の 2 つの因子が相乗効果を生 じさせ, 酸化劣化が深さ方向へと進行したと考えられる.

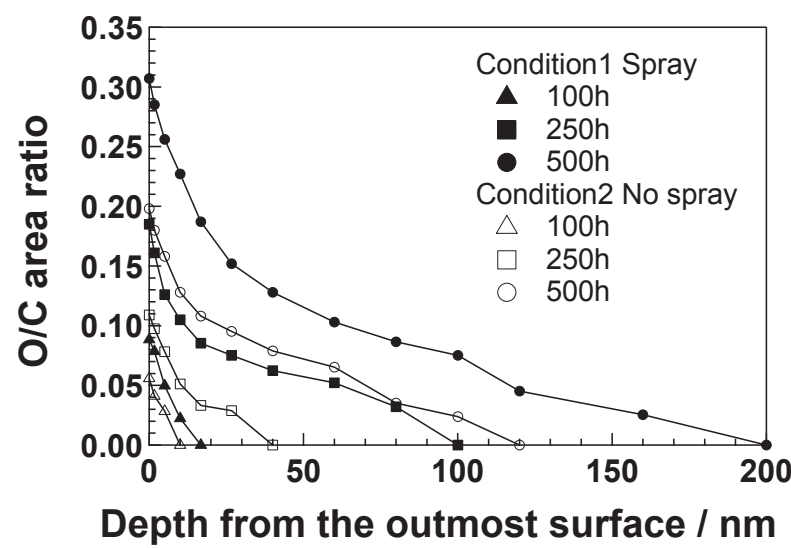

Fig.5 O/C area ratio for PP oxidized under the condition of (1)(spray) and (2)(No spray). 


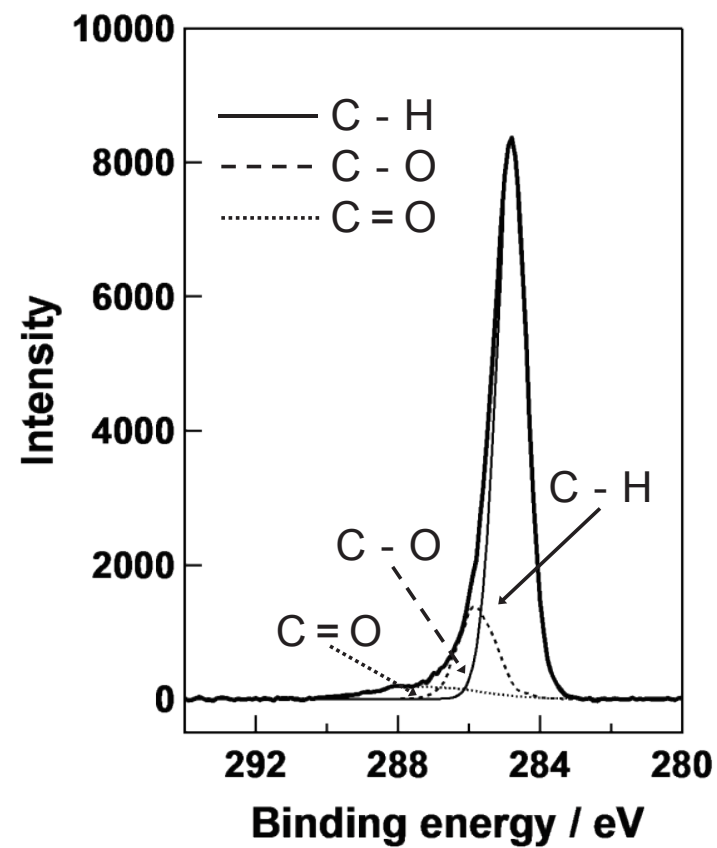

Fig.6 C1s spectra for PP oxidized for 500hours under the condition of (1)(Spray).

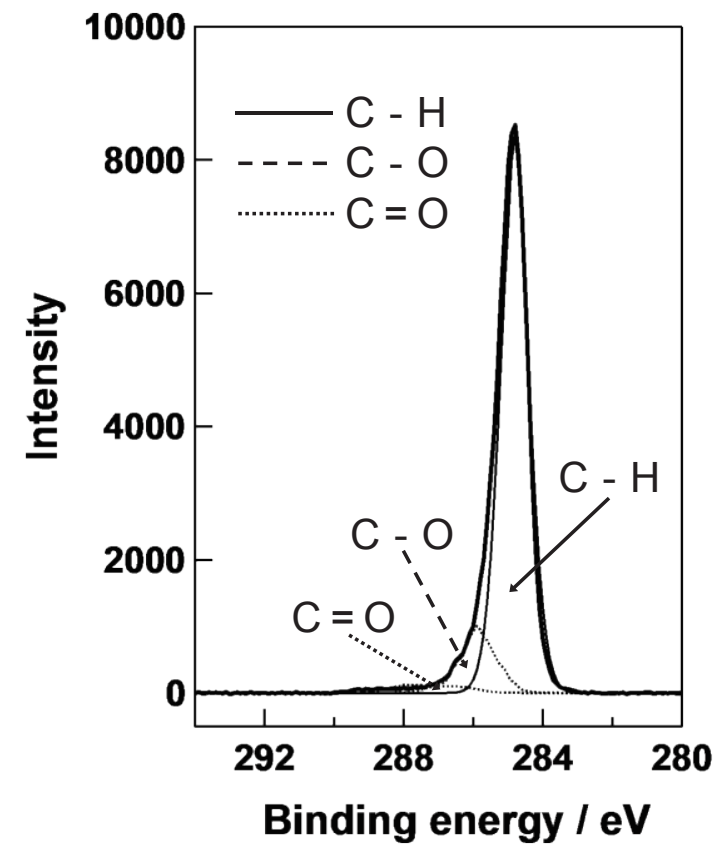

Fig.7 C1s spectra for PP oxidized for 500hours under the condition of (2)(No spray).

\section{3 光と水分が高次構造の変化に及ぼす影響}

Fig. 8 は「水噴霧あり」「水噴霧なし」の各照射時間に おける first scan における DSC 曲線である。「水噴霧あ り」の吸熱ピークは未処理と比べ照射 100 時間では約 $1{ }^{\circ} \mathrm{C}$ と僅かな低下であったが，照射 250 時間で約 $4{ }^{\circ} \mathrm{C}$ ，照射 500 時間で約 $8^{\circ} \mathrm{C}$ と急激に低温側へシフトし，ピーク形 状も低温側でブロード化した。一方，「水噴霧なし」にお ける吸熱ピークの低下は照射 250 時間まで約 $2^{\circ} \mathrm{C}$ と僅か

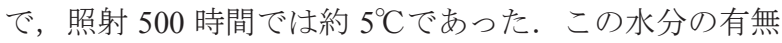
による劣化挙動の差異はカルボニル Index（Fig. 3）に基 づく酸化劣化の進行度合いと相関が認められた。これは, 酸化劣化の進行により暴露面近傍において PP の fold 型
結晶構造が崩壊したためと考えられる ${ }^{15)}$. 結晶部では非 結晶部と比べ分子鎖間の距離が近いため分子間力が強 く強固であるが，結晶構造の崩壊により，吸熱ピークの 低下が生じたといえる ${ }^{16)}$

吸熱ピークの低下が著しい「水噴霧あり」の照射 250 時間と照射 500 時間，「水噴霧なし」の照射 500 時間で は, PP の低分子化が推察されたため, TGによる熱分解 挙動をもとに低分子化傾向を調べた ${ }^{17)}$. Fig. 9 は各照射 時間における TG 曲線である。 ベースラインと熱分解曲 線の傾きが最大となる接線の交点から求めた熱分解温 度（ $\mathrm{T}_{\mathrm{d}}$ ) は, Table 3 に示すように「水噴霧あり」の方が 「水噴霧なし」よりも照射時間の経過に伴い $\mathrm{T}_{\mathrm{d}}$ の低温 化が生じていた. よって, 光照射時の水分の付加は低分 子化を促進されるといえる.
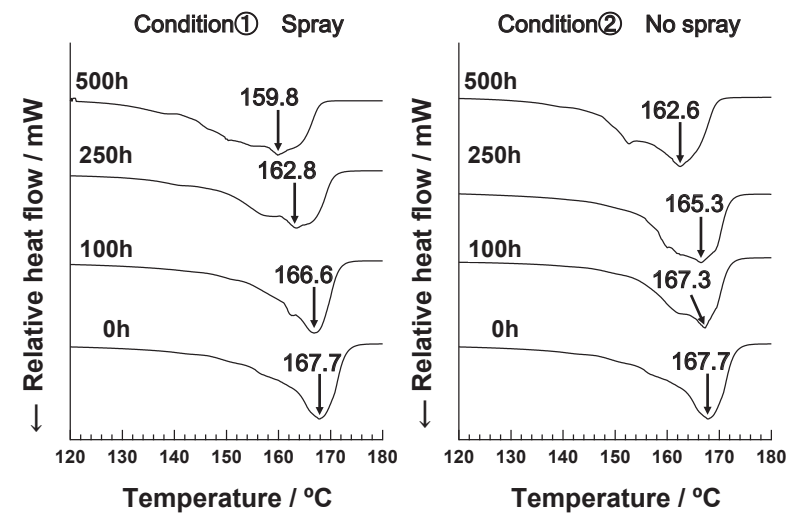

Fig.8 DSC first-scan charts for PP oxidized under the condition of (1)(spray) and (2)(No spray).

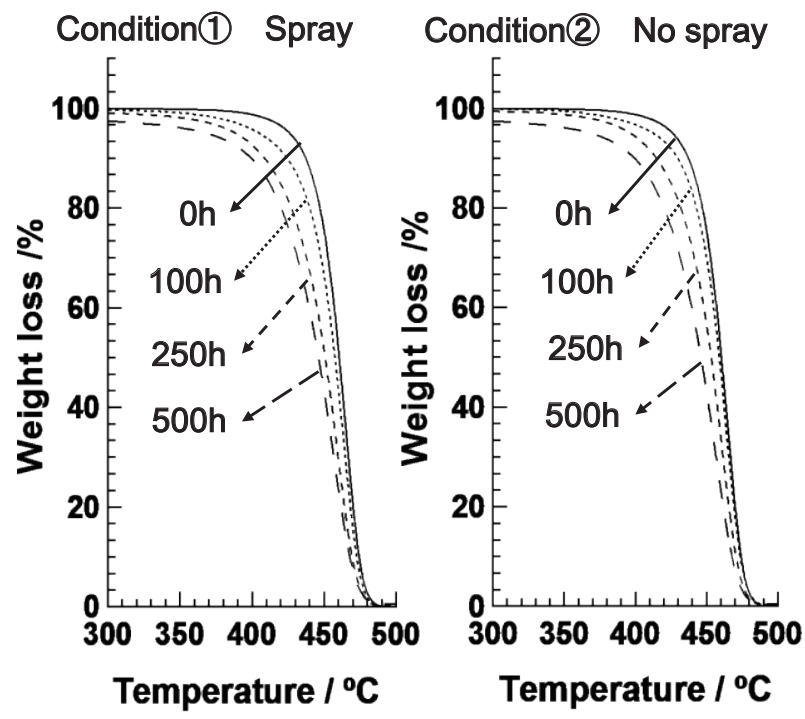

Fig.9 Thermal behavior for PP oxidized under the condition of (1) (spray) and (2)(No spray) by using TG (Thermo Gravimetric).

Table 3 Change of $T_{d}$ before and after Xenon irradiation.

\begin{tabular}{ccc}
\hline \multirow{2}{*}{ Irradiation time } & Condition(1) & Condition(2) \\
\cline { 2 - 3 } & $\mathrm{T}_{\mathrm{d}} /{ }^{\circ} \mathrm{C}$ & $\mathrm{T}_{\mathrm{d}} /{ }^{\circ} \mathrm{C}$ \\
\hline $50 \mathrm{~h}$ & 446 & 446 \\
$100 \mathrm{~h}$ & 441 & 442 \\
$250 \mathrm{~h}$ & 428 & 432 \\
$500 \mathrm{~h}$ & 420 & 427 \\
\hline & \multicolumn{2}{c}{$\mathrm{T}_{\mathrm{d}}:$ decomposition temperature }
\end{tabular}




\section{4 水分が物性の低下に及ぼす影響}

光劣化の進行によって酸化を受ける部分は暴露表面 もしくはその近傍に限定されるものの，高次構造や分子 構造の変化は機械的強度の低下に大きな影響を及ぼす と考えられる。なぜなら，暴露表面上の僅かなき裂や高 次構造の不均一化は応力集中を引き起し破壊へとつな がるからである。

Fig. 10 はシャルピー衝撃試験強度，Fig. 11 は引張降 伏時伸びと照射時間の関係である．照射 100 時間以降で は「水噴霧あり」では「水噴霧なし」よりもシャルピー 衝撃強度の低下率が大きく, 引張降伏時伸びも同様に水 分の影響を受け，低下率に明瞭な差異が認められた。

Fig. 12 は「未処理」「水噴霧あり」「水噴霧なし」「熱 のみ（水噴霧なし，光照射なし）」の条件下で照射 500 時 間後の暴露表面におけるSEM画像である.「水噴霧あり」 のみ凹凸状の荒れ，微少のき裂が多数発生していること から，シャルピー衝撃強度と伸びの低下に大きく起因し ているといえる ${ }^{18)}$.

本研究に供した試料は前記したように酸化防止剂の 添加量は極めて少ないことから，水噴霧時に酸化防止剤 が流出した影響はなく，水分のみが物性の低下に大きく 寄与しているといえる. 酸化劣化が進行した暴露面近傍 では，カール・フィシャー法により劣化生成物のカルボ ニル基やヒドロキシ基による水分吸着が確認された。吸 着された水分は酸化劣化を暴露表面近傍で著しく加速 させると同時に試料の深さ方向へも進行させる．分子鎖 に浸入した水分は僅かな膨潤現象を生み，分子間力が低 下寸る。さらに，結晶構造の崩壊や低分子化により暴露 表面近傍では脆化層が形成され，発生したき裂等は外力 からの応力集中を引き起こす。よって，衝撃吸収や柔軟 性に関する物性の低下を招いたと考えられる ${ }^{19), 20) . ~}$

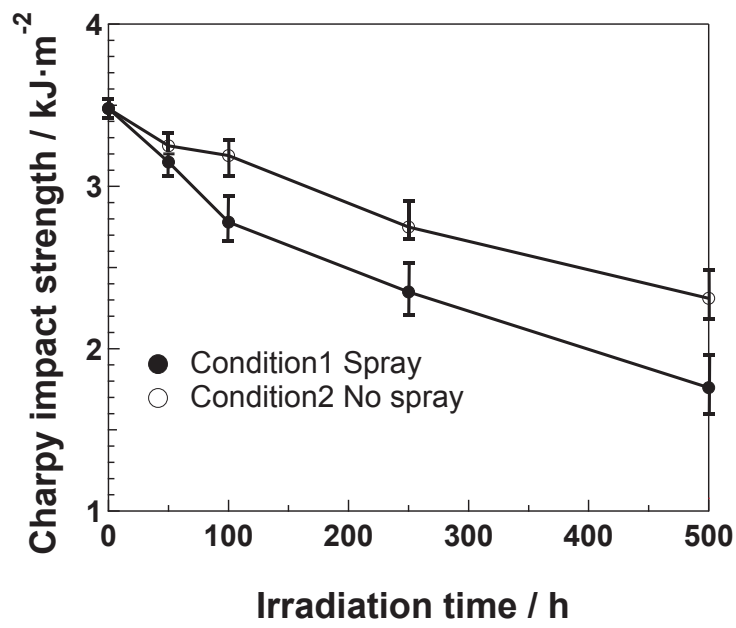

Fig.10 Time dependence of Charpy impact strength for PP oxidized under the condition (1)(spray) and (2)(No spray).

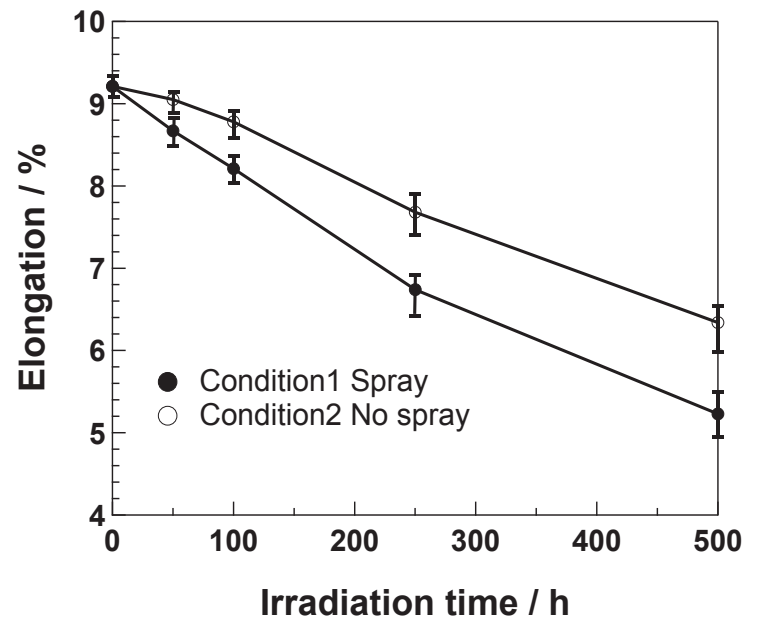

Fig.11 Time dependence of elongation at yield point for PP oxidized under the condition (1)(spray) and (2)(No spray).
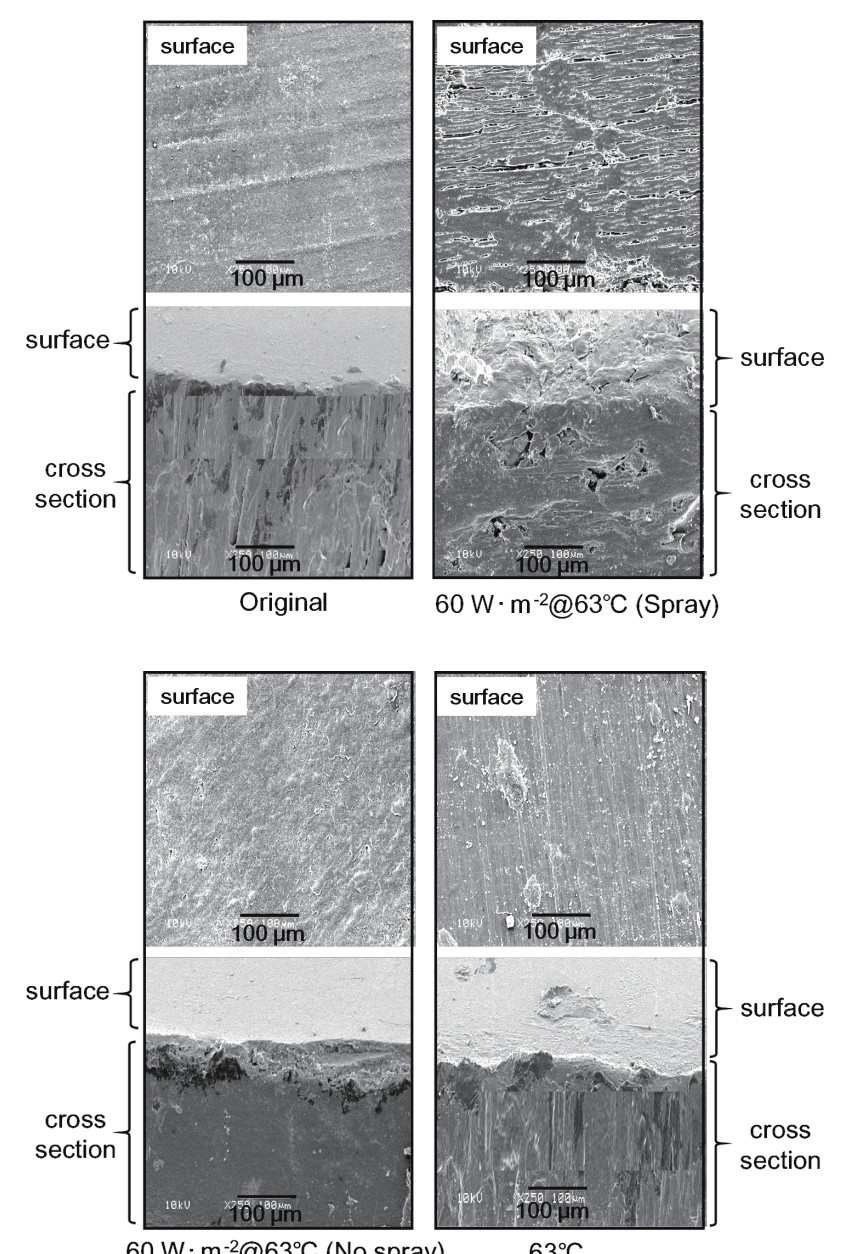

Fig.12 SEM images for the outermost surface and the cross section of PP. The magnification of the images was 250 .

\section{4 結言}

光照射中に水分を付加させると, 光照射のみと比べ, 光と水の相乗効果により PP の光劣化が促進される. キ セノンランプによる照射 250 時間に達すると水噴霧の有 無による光劣化の進行の差異はより明瞭となる. 水分は 特に暴露面近傍で光劣化を著しく助長させ，カルボニル 
基やヒドロキシ基等の親水基を増加させる．この親水性 基の付与は水分をよりポリマー内へ吸着させ，吸着水分 量の上昇と伴に PP の光劣化が進行する.「水噴霧あり」 の照射 500 時間の試料では, 酸化生成物は暴露面近傍で 著しく増加するとともに深さ方向にもその存在が認め られた。

光照射時の水分の付加は光照射のみに比べ, PPのfold 型の結晶構造をより崩壊させ，同時に主鎖切断に伴う低 分子化も進行させる。 その結果, 衝撃強度や降伏時伸び の低下を引き起こした，したがって，促進暴露試験にお ける水分がPPの光劣化に及ぼす促進性を分子構造およ び物性值の両面から定量的に掌握することができた。

\section{参考 文 献}

1) A. T. Michel and S. L. Billington, "Characterization of poly-hydroxybutyrate films and hemp fiber rein forced composites exposed to accelerated weathering", Polymer Degradation and Stability, Vol.97, pp.870878 (2012).

2) C. H. Wu, C. Y. Chang and J. P. Lin, "Effects of moisture on pyrolysis of polypropylene", Journal of Environmental Engineering, Vol.124, pp.892-946 (1998).

3) S.G. Karpova and A. A. Popov, "Kinetics of ozone oxidation of oriented polypropylene and high-density polyethylene", Russian Journal of Physical Chemistry, Vol.2, pp.940-946 (2008).

4) G. Meijiers and P. Gijsman, "Influence of environmental concentrations of ozone on thermooxidative degradation of PP", Polymer Degradation and Stability, Vol.74, pp.387-391 (2001).

5) Y. Ohtake, T. Kobayashi, H. Asabe, M. Yabuki and K. Ono, "Study on biodegradation mechanism of LDPE concealed in soil for over 32 years", Nippon Kagakukaishi, Vol.4, pp.325-333 (1996).

6) M. Sudhakar, M. Doble, P. S. Murthy and R. Venkatesan, "Marine microbe-mediated biodegradation of low- and high-density polyethylens", International biodeterioration \& Biodegradation, Vol.61, pp.203-213 (2008).

7) L. S. Wang, S. X. Cheng and R. X. Zhuo, "Synthesis and hydrolytic degradation of aliphatic polycarbonate based on dihydroxyacetone", Polymer Science, Vol.55, pp.604-610 (2013).

8) A. Ballara and J. Verdu, "Physical aspects of the hydrolysis of polyethylene terephthalate", Polymer Degradation and Stability, Vol.26, pp.361-374 (1989).

9) W. N. Ayre, S. P. Denyer and S. L. Evans, "Ageing and moisture uptake in polymethyl methacrylate (PMMA) bone cements", Journal of the Mechanical Behavior of Biomedical Materials, Vol.32, pp.76-88 (2014).
10) M. Gonokami, Y. Ohtake and S. Kawahara, "Dissolution behavior of the antioxidant in PP in tap water and evaluation of the polymer degradation", Nippon Gomukyokaishi, Vol.84, No.11, pp.176-181 (2011).

11) A. Nojiri and T. Sawasaki, "Radiation crosslinking of polypropylene", Radiation physics and Chemistry, Vol.26, No.3, pp.339-346 (1985).

12) K. Rajakumar, V. Sarasvathy, A. T. Chelvan, R. Chitra and C. T. Vijayakumar, "Natural weathering studies of polypropylene", Vol.17, pp.191-202 (2009).

13) X. Colom, J. Canavate, J. J. Sunol, P. Pages, J. Saurina and F. Carrasco, "Natural and artificial aging of polypropylene-polyethylene copolymers", Journal of Polymers Science, Vol.87, pp.1685-1692 (2003).

14) L. Tang, Q. Wu and B. Qu, "The effects of chemical structure and synthesis method on photodegradation of polypropylene", Journal of Applied Polymer Science, Vol.95, pp.270-279 (2005)

15) G. A. Meligi, H. A. A. El-Rehim, E. Hegazy, A. M. Ali and A. M. Rabie, "Degradation of polypropylene and polyprop/starch blends", Polymers \& Polymer Composites, Vol.17, No.4, pp.265-272 (2009).

16) N. Olivares, P. Tiemblo and J. M. Gomez-Elvira, "Physicochemical processes along the early stage of the thermal degradation of isotactic polypropylene I . Evolution of the $r$ relaxation under oxidative conditions", Polymer Degradation and Stability, Vol.65, pp.297-302 (1999).

17) M. Xin, Y. Ma, K. Xu and M. Chen, "Gallate derivatives as antioxidant additives for polypropylene”, Journal of Applied Polymer Science, Vol.3, pp.131-138 (2014).

18) K. Rajakumar, V. Sarasvathy, A. T. Chelvan, R. Chitra and C. T. Vijayakumar, "Effect of iron carboxylates on the photodegradability of polypropylene. II . Artificial weathering studies", Journal of Applied Polymer Science, Vol.123, pp.2968-2976 (2012).

19) L. L. Frenandes, C. A. Freitas, N. R. Demarquette and G. J. M. Fechine, "Photodegradation of thermodegraded polypropylene/ high impact polystyrene blends : mechanical properties", Journal of Applied Polymer Science, Vol.120, pp.770-779 (2011).

20) R. F. Navaro, J. R. M. d'Almedia and M. S. Rabello, "Elastic properties of degraded polypropylene", Journal of materials Science, Vol.42, pp.2167-2174 (2007). 